\title{
British radio drama and the avant-garde in the 1950s
}

Hugh Chignell

Bournemouth University, $\mathrm{UK}^{1}$

Correspondence: Professor Hugh Chignell, Faculty of Media and Communication, Bournemouth University, Poole, Dorset, BH12 5BB, UK. +44 (0)1202 961393

Email: hchignell@bournemouth.ac.uk 


\title{
British radio drama and the avant-garde in the 1950s
}

\begin{abstract}
The BBC in the 1950s was a conservative and cautious institution. British theatre was at the same time largely commercial and offered a glamorous distraction from wider social and political realities. During the decade, however, new avant-garde approaches to drama emerged, both on the stage and on radio. The avant-garde was particularly vibrant in Paris where Samuel Beckett was beginning to challenge theatrical orthodoxies. Initially, managers and producers in BBC radio rejected a radio version of Beckett's, Waiting for Godot and other experimental work was viewed with distaste but eventually Beckett was accepted and commissioned to write All That Fall (1957), a masterpiece of radio drama. Other Beckett broadcasts followed, including more writing for radio, extracts from his novels and radio versions of his stage plays as well as plays by the experimental radio dramatist, Giles Cooper.

This article examines the different change agents which enabled an initially reluctant BBC to convert enthusiastically to the avant-garde. A networked group of younger producers, men and women, played a vital role in the acceptance of Beckett as did the striking pragmatism of senior radio managers. A willingness to accept the transnational cultural flow from Paris to London was also an important factor. The attempt to reinvent radio drama using 'radiophonic' sound effects (pioneered in Paris) was another factor for change and this was encouraged by growing competition from television drama on the BBC and ITV. The acceptance and eventual championing of avant-garde drama in the late 1950s reveals how the BBC's commitment to public service broadcasting facilitated a flowering of experimental and avant-garde drama during radio drama’s golden age.
\end{abstract}

Key Words Radio drama | BBC | Samuel Beckett | Giles Cooper | avantgarde drama | transnational flow | radiophonic sound | public service broadcasting 


\section{British radio drama and the avant-garde in the 1950s}

\section{Introduction}

Almost everything about Britain in the 1950s seems to be conservative and cautious. For most of the decade there was a Conservative government, the Suez crisis of 1956 was born out of an attempt to reassert imperial power, the senior positions in society were largely held by men, the products of top public schools and a handful of Oxford and Cambridge colleges while the Lord Chamberlain censored the theatre as he had done since 1737. There was as David Pattie states so succinctly, a sense that Britain was run by 'a self-perpetuating, self-selecting elite, impervious to new ideas and new social movements'. ${ }^{1}$ Conservatism was also expressed in British culture; deference to those in positions of authority (soon to be ridiculed by the satirical movement of the early 1960s), the formality of dress and appearance, traditional gender roles and so on. Sitting at the heart of this most conservative of decades was the BBC with its devoted attention to anything royal and its calendrical duty to mark the important dates of the year. ${ }^{2}$ Photographs of BBC staff from the time show pipe-smoking men in suits and ties and female secretaries. The Director General of the BBC (1952-59) was Lieutenant General Sir Ian Jacob and the Chairman of the BBC was Sir Alexander Cadogan, the son of an earl. As Kate Murphy has described in her recent book on women and the BBC, although there were several women at Director level in the organisation in the pre-war period, by the 1950s gender discrimination had become entrenched and no women occupied such a senior position. ${ }^{3}$

Paris in the 1950s must have seemed a very different place. The bohemian café culture attracted a constellation of literary types including Sartre, de Beauvoir, Gertrude Stein, Godard, Hemmingway, Ionesco and the Irish novelist and playwrite, Samuel Beckett. Paris was the centre of a literary and intellectual renaissance which must have appeared intensely glamorous to British eyes. Little wonder then that the BBC had a 'Paris Representative', the very able Cecilia Reeves, who kept an eye on the French stage, and no surprise that British drama producers felt it necessary to visit 
Paris to find out what was going on. ${ }^{4}$ Here it was on 5 January 1953, at the Theatre de Babylon, that Beckett's En Attendant au Godot was first performed. While audiences in London were treated to the banality of much of the British theatre at the time, a good night out for a bourgeois audience (expecting an evening's theatrical entertainment complete with proper characters, plot, costumes and scenery), in Paris, Beckett's audiences saw a play with no characters, plot or scenery; famously a play in which 'nothing happens, twice'. 5 This was a play 'so enigmatic, so exasperating, so complex, and so uncompromising in its refusal to conform to any of the accepted ideas of dramatic construction'. ${ }^{6}$

Paris may have felt a long way away from London in 1953, and Beckett's troubling work very distant from the comfortable offerings on the London stage, but these two worlds were to meet with major implications for British drama. The latter half of the 1950s would be a time when the BBC became increasingly enthusiastic about Beckett and other representatives of the avant-garde. How the seemingly cautious BBC came to embrace that most unorthodox and challenging of writers and other avant-garde dramatists is the subject of this article.

\section{British theatre in the 1950s}

It is tempting, although probably mistaken, to see the 1950s in Britain as essentially ruptured, a decade of two halves; before and after the 1956 Suez crisis, before and after the launch of ITV in 1955 and either side of John Osborne’s sensational play, Look Back in Anger which heralded a move away from the farces and drawing room dramas that dominated the London stage towards a new 'kitchen sink' realism. While there is something useful in such a bifurcation it is also problematic because of the consistencies across the decade. Traditional values of class and gender difference, deference, conformity and chronic political cronyism barely changed. Nevertheless it is important to acknowledge the conflicts within the establishment and between generations in post-war Britain, indeed essential in order to understand the success of Beckett and the BBC. It is possible to speak of 'culture wars' at the time and the growing tension between the establishment and a more radical younger generation that was to have such a decisive impact in the 1960s. The gulf between the old and the new was clearly expressed in the theatre where the old guard of Somerset Maugham, Noel Coward, T.S.Eliot and others looked on in horror at the arrival of a 
new literary generation including Philip Larkin, John Osborne, Kingsley Amis and the theatre reviewers, Kenneth Tynan and Harold Hobson.

In his discussion of British theatre in the 1950s, David Pattie focuses his attention on the commercialism of the London theatre, the system of local 'repertory' companies and the dead hand of the Lord Chamberlain. ${ }^{7}$ The large theatres of the West End were controlled by entrepreneurial management groups and in particular H.M.Tennent Ltd. Companies like Tennent were mainly interested in large audiences, long runs and profit. ${ }^{8}$ There was, according to the theatre critic, Michael Billington, little to shock in the plays of the 'West End' which featured 'light comedies with titles like My Wife's Lodger, Mary Had a Little, The White Sheep of the Family and Wagonload of Monkeys' (2007, p.56). ${ }^{9}$ Meanwhile in the provinces repertory companies were something of a treadmill, producing light comedies and thrillers on a weekly basis. This was a dull and uninspiring formula that would struggle to compete with the television drama from both the BBC and the new Independent Television (ITV). In 1956 the American playwright, Arthur Miller was highly critical of British theatre (with the notable exception of Look Back in Anger). ${ }^{10}$ For Miller the British stage was an irrelevant and gaudy distraction from British society and its problems, it was 'hermetically sealed' from the world around it. A similar point was made by the prominent Sunday Times theatre critic, Harold Hobson who, following a visit to Paris returned to London and observed that the theatre was 'shut off by sound proof walls' from the reality of 1950s Britain. ${ }^{11}$

The shock generated by Look Back in Anger with its regional accents and famously realist 'kitchen sink' domestic set makes sense when viewed against the theatre of H.M.Tennent. Realist drama of the mid 1950s can be seen as 'an impassioned rejection of this very commercial success ... an obsession with glamour, a refusal to stage works that glanced at contemporary life ... a continual representation of upper middle class milieus.' ${ }^{12}$ The leading ladies in Tennent productions often wore the latest Dior fashions imported from Paris to add to the glamour and luxury of the productions. Not only did so much British drama represent higher class life-styles, it was also politically reactionary. In November 1956, just six months after the first performance of Look Back in Anger, Noël Coward's Nude With Violin opened starring John Gielgud. This was a satire on the pretentiousness of modern art and was a play characterised by 'casual racism', fun being made of a servant daring to act outside his class and a sneering attitude towards improved 
educational opportunities, 'all symptomatic of the conservatism of much West End theatre of the early 1950s'. ${ }^{13}$ Despite the momentous changes heralded by dramatists like Beckett, Osborne, Pinter and others, Coward's play ran for over a year to large, nightly audiences and is evidence that it is 'erroneous to talk of a Royal court revolution, dating from the premiers of Look Back in Anger in May 1956, that swept all before it.' 14

British theatre in the 1950s was in a period of transition. The Arts council, established on 9 August 1946, had modest success encouraging new drama and was important in support for the Royal Court Theatre but there was no Royal Shakespeare Company or National Theatre, these would arrive in the 1960s when the commercial hold on the stage was weaker and state support for the arts, through the Arts Council, became decisive. The events discussed in this article were set against a theatrical backdrop of a commercial, glamorous but often socially and politically irrelevant theatre. There were of course exceptions and it would be simplistic to dismiss all mainstream theatre at the time. Despite the prevalence of drawing rooms, popular West End plays could depict tensions around class, gender and sexuality. So, for example, Terence Rattigan's The Winslow Boy (1947) ran for 478 performances at the Lyric, Shaftesbury Avenue and expressed the unresolved tensions within the author about class and politics. ${ }^{15}$ Two further features of 1950s theatre are important to note. The Lord Chancellor censored all stage performances until 1968. Between 1945 and 1955, a remarkable 42 plays were banned mainly for references to sex, including homosexuality. ${ }^{16}$ This censorship could be avoided if a play was performed in a private club and the Arts Theatre Club was a very important venue for innovative drama. Another feature of the London stage was the influence of French drama. The plays of Sartre, Genet, Anouilh and other French writers were performed in translation, French productions came to Britain and as already mentioned British producers and critics made regular visits to Paris. Shellard goes so far as to describe French dominance of London theatre as 'theatrical imperialism'. ${ }^{17}$ Other important transnational influences were from the U.S., notably the plays of Arthur Miller and Tennessee Wiliams (Streetcar Named Desire) and from Germany, the very significant arrival of Brecht's Berliner Ensemble for a season in 1956.

Despite the commercial dominance of British theatre and the dead hand of the censor and no doubt inspired by continental and American influences, some experimental plays were performed. Look Back in Anger was performed by the 
English Stage Company at the Royal Court Theatre and benefitted from Arts Council subsidy. Meanwhile the 25 year old, Peter Hall directed Eugene Ionesco's The Lesson, the first British performance of an Ionesco play, at the Arts Theatre Club in March 1955. ${ }^{18}$ This was followed on $3^{\text {rd }}$ August in the same year at the same theatre by Waiting for Godot also directed by Peter Hall. The second half of the 1950s was a time of change in British theatre and given the close proximity between the London stage and $\mathrm{BBC}$ radio drama this was another factor stimulating change in the broadcast repertoire.

\section{The $B B C$ and radio drama}

Institutional histories of the BBC, most notably Asa Briggs' five volume history of British broadcasting, tend towards an institutional approach. ${ }^{19}$ In recent years, however, there has been greater acknowledgement of the role of individual actors in the organisation and the crucial contribution individuals made to the organisation as a whole. $^{20}$ If it is true that the BBC of the 1950s was indeed a conservative and cautious place that is partly the result of the influence of one or two senior figures. The news department was run by the ultra-cautious Tahu Hole and Drama was led by the man who had presided over radio drama since 1929, Val Gielgud. ${ }^{21}$ The acceptance of avant-garde drama at the BBC, including the work of Beckett, owes a lot to this contradictory figure. At first glance, Gielgud was a self-confessed cultural conservative who established his credentials during the war by advocating and enforcing a policy of 'national theatre'. Drama was instrumental to the war effort and plays which reinforced a proud national identity were of course the priority. That approach to radio drama, prioritising the classics of British drama (especially Shakespeare) and adaptations of popular but classic novels was a policy which Gielgud continued in the 1950s. He was, unsurprisingly, vehemently opposed to the introduction of American-style radio soaps or serials. In his exit interview from the BBC he simply stated that he 'hated' soaps and held well-loved and popular programmes such as The Archers and Mrs Dale's Diary 'in contempt'. ${ }^{22}$ Gielgud's account of his own career and attitudes in this interview reveal a highly complex and often contradictory personality; a man who was both profoundly conservative but capable of grasping the new. 
Gielgud was eventually succeeded in 1963 by Martin Esslin, a champion of all things 'absurd'. ${ }^{23}$ Esslin describes being taken out to lunch by Gielgud and told, 'I hate Brecht, I hate Beckett, I hate Pinter. But I know what my duty is. That's why I've appointed you to deal with these people. ${ }^{24}$ Gielgud's reference to duty here, his pragmatic sense of what it meant to be a BBC employee is particularly significant. Conservative and pragmatic though he was, Gielgud was an early and committed supporter of the work of the experimental dramatist, Giles Cooper; he was not therefore opposed to experimental or challenging drama per se.

The general retreat into predictably under Gielgud in the early 1950s did not go unnoticed higher up the BBC and the Director of Sound Broadcasting, Lindsey Wellington called a meeting of drama producers on 3 November 1955 to discuss the subject of 'experimentalism in drama programmes'. It is clear from the flurry of memoranda which followed the meeting that Drama had been subject to a severe critique by Wellington and in particular for the lack of experimentation in drama output. The script editor, Barbara Bray (soon to become a key figure in Beckett's work and life) wrote to Gielgud following the meeting and her words are particularly perceptive and useful,

... good, unconventional ideas are sometimes stifled for lack of a more encouraging atmosphere. [...] If the Programme Planners would agree to break with the old routines, so that the public might be more prepared to listen with an open mind, we could increase the proportion of unconventional material in our output. $^{25}$ (emphasis as in the original)

This was Gielgud's own written response to Wellington (note the implicit suggestions that the fault lay with junior staff),

Following upon the recent meeting when, with every justification, you passed certain generally critical observations regarding the work of this department, and expressed your wish for the injection of a considerable new dose of 'experimentalism' into our output as a whole, I took the occasion of a departmental meeting to lay the criticism and the suggestions squarely before my producers... ${ }^{26}$ 
In the same memo, Gielgud accepted the need to close the radio drama repertory company agreeing that 'its disbandment would undoubtedly tend to reduce the apparent all-over sameness of dramatic productions'. Gielgud's apparent capitulation to external criticism of his department reflects his complex character; at times resolutely opposed to new dramatic writing (he was always highly critical of Pinter for example) but also prepared to allow others to take the lead against his own personal preferences. The pressure Gielgud was under to do better was partly the result of the success of Features Department which was responsible for a host of production triumphs, annoyingly for Gielgud some of which were dramas. David Jones In Parenthesis (1946), Louis MacNeice's The Dark Tower (1947) and, most successful of all, Dylan Thomas's Under Milk Wood (1954) all served to emphasise the sparkling creativity of Features under Lawrence Gilliam and the relatively pedestrian output of Drama. In addition the launch of ITV in the same year also added to a sense of crisis in the Drama faced with increased competition for an audience already moving away to evening television.

The Third Programme was created in 1946 as a home for 'cultural programming' and was an important outlet for drama. Its Controller was John Morris, an extraordinary appointment for such a prestigious cultural position, a former solider, he was approved of by Sir Ian Jacob as a military man but as his predecessor in the role, Harman Grisewood, stated, he was not part of the literary scene and was principally an administrator. ${ }^{27}$ Insofar as it is possible to read someone's character from the archived memoranda, Morris appears above all to have been a pragmatist. He might not have fully understood the bewildering world of avant-garde theatre but he was a shrewd operator who, like Gielgud, was prepared to accept programmes he did not like or understand out of a loyalty to the BBC. ${ }^{28}$

The other main protagonists in the arrival of the avant-garde at the BBC were a younger group of drama producers. The best known of this group are Donald McWhinnie, who produced Beckett's first radio play and was an enthusiastic admirer of his and Michael Bakewell who is mainly associated with Harold Pinter. McWhinnie became Gielgud's assistant in 1953 and he seemed to have many of the qualities Gielgud lacked and in particular a keen appreciation of new writers. For Kate Whitehead the arrival of McWhinnie is 'generally regarded as the turning point in terms of a preference for the avant-garde, and also influenced the gradual eclipse of Features department'. ${ }^{29}$ The radio critic, Ian Rodger even talked of the 'dramatic 
revolution of 1953 ' to describe McWhinnie's arrival. ${ }^{30}$ Perhaps as important, if not more so, for Beckett's radio career was the part played by the script editor, Barbara Bray, who not only championed Beckett's work but other significant new writers and especially Giles Cooper and Rhys (L.R.) Adrian. Another name which appears regularly in the to and fro of Drama department memoranda is the Paris Representative of the BBC, Cecilia Reeves. She was an important point of contact between Beckett and the BBC and importantly she write to him to ask him to write a drama for radio. $^{31}$

Given the relative neglect of women in histories of the BBC it is worth pausing here to reflect on the role of Barbara Bray and Cecilia Reeves, difficult though that is given the lack of written accounts of their BBC careers. Anthony Cronin, in his biography of Beckett is clear about the importance of Bray not only in the BBC and its relations with Beckett but also in Beckett's life describing their relationship as 'a close personal one’. ${ }^{32}$ Barbara Bray was to become a central figure in Beckett's life and her role as the chief broker between him and the BBC in the late 1950s was clearly extremely important, perhaps without her perceptive understanding of Beckett and his work he would not have produced the work for radio which he did. In Bray's oral history interview upon leaving the BBC she describes, with considerable emotion, working with Beckett as 'out of this world'. Cecilia Reeves is a shadowy figure in the available written archives of the BBC but her role in Paris clearly placed her at the heart of the negotiations with Beckett and others. The entry for her in the Oxford Dictionary of National Biography is particularly helpful,

The post-war years saw a much increased interest in French cultural life on the part of BBC radio, with the newly created Third Programme providing an outlet for many distinguished French voices. This owed much to Cecilia Reeves's unparalleled network of contacts among French intellectuals, journalists and politicians, who came to the studios on Avenue Hoche to make their contribution to Anglo-French understanding. ${ }^{33}$

Barbara Bray and Cecilia Reeves were crucial in the positive reception of the Parisbased avant-garde although the almost total absence of documentary evidence makes it hard to assess their precise influence. 
With the conflicted characters of Gielgud and Morris managing radio drama and the younger producers urging innovation, the BBC's response to the avant-garde was complex and at times contradictory. There was no simple BBC position on new and experimental drama either within the organisation or even within some of the key individuals who led it.

\section{Beckett and the BBC}

So much has been written about Beckett, his life and work, but for the benefit of those not familiar with the man or his writing a few basic facts are necessary to understand the overall argument presented here. Born in Dublin in 1906, Beckett took up an academic post in Paris in 1928 and remained there for the rest of his life. He soon quit the routine of academia to become a writer and was closely associated with his fellow countryman who had also moved to Paris, James Joyce. By the early 1950s, Beckett had produced a number of novels, all in French (Watt, Malloy, Mallone Dies) none of which had sold well but all of which confirmed his status as a challenging writer with a profoundly pessimistic view of humanity. En Attendant Godot made Beckett famous and is undoubtedly one of the most important and influential plays of the twentieth century. The events following the first performance of Godot on 3 March 1953 at the Théâtre de Babylon in Paris up to the end of the 1950s are the main focus of this article and although Beckett was not the only avant-garde writer to have his work performed by BBC Radio Drama he was probably the most important.

Cecilia Reeves saw an early performance of En Attendant au Godard with the producer Rayner Heppenstall and sent a memorandum to Gielgud's newly appointed deputy, Donald McWhinnie two months after the first night. ${ }^{34}$ Reeves comments were mixed, 'the first half of it is extraordinarily effective on the stage but it ceased to be convincing after we had a drink at the interval, so that it would probably be easier to hold the attention with a radio version. ${ }^{35}$ The writer and BBC script editor, E.J.King Bull also saw Godot at this time and sent a memorandum directly to Val Gielgud but his rather unsophisticated reading of the play was that it was simply a comedy. He thought the play was 'pretty funny' and contained a 'recurring gag' and even likened Beckett to the writer of the war-time comedy series It's That Man Again,

Ted Kavanagh. ${ }^{36}$ Gielgud's reply, or at least the next memorandum in the file, came 
six months later and was predictable; 'I am left with the impression of something that is basically "phoney" [...] I shall advise C.T.P. [John Morris, Controller Third Programme] that in my view we should do well to drop the subject." ${ }^{37}$ The BBC did not broadcast Godot (which Beckett soon translated into English) for another 7 years but Beckett, and the avant-garde, did not go away.

The Arts Theatre Club, a small venue but one which could avoid the attention of the Lord Chancellor, put on a performance of Eugene Ionesco's The Lesson, directed by the 25 year old Peter Hall, in March 1955. Ionesco fitted neatly into the category of French 'absurdist' and it was perhaps no surprise that a few months later, Peter Hall directed the first British performance of Waiting for Godot in English, Michael Billington explains why the play caused such a sensation,

To understand the shock and dismay Beckett's play caused when first staged at the Arts in August 1955, one has to remember how different the rituals of theatre-going then were [...] audiences expected to be transported by the dramatist into a word of heightened reality. ${ }^{38}$

These performances of avant-garde plays at the Arts Theatre Club served to build up the pressure in the Drama department to accommodate Beckett in some way. Within Radio Drama a steady stream of memoranda reached Gielgud praising Godot. Helena Wood sent these words via Barbara Bray, probably having seen the play at the Arts Theatre Club;

It is very different from the usual thesis play in that the whole statement is explicit, sometimes even bewilderingly so. I find it stimulating, moving and exciting, full of dramatic vitality and significance, even when I could not make any sense out of it, and always the work of a poet. ${ }^{39}$

Another internal memorandum, from the producer, Raymond Raikes, to Gielgud is more demanding,

May I suggest we record and broadcast this production as soon as possible lest it be said that the BBC has once again "missed the boat". 40 
Despite the initial resistance to broadcasting Beckett's work, during 1956 a number of experimental radio dramas were broadcast. The dramatist, Giles Cooper made the transition from an established career writing for the Home Service and the Light Programme to the Third Programme where Mathry Beacon was broadcast on $18^{\text {th }}$ June 1956. The play was commissioned by Barbara Bray, produced by Donald McWhinnie and won the Prix Italia (the use of 'radiophonic' sound in Mathry Beacon is discussed later in this article). In the same year, Ionesco's Le Photo du Colonel and Rhys Adrian's The Man on the Gate were also broadcast on the Third Programme. However, these experimental plays were not welcomed by the Controller of the Third, John Morris. In a memorandum of 26 April 1957 to Val Gielgud, he expressed his strong dislike of Cooper's The Disagreeable Oyster ('it would be dishonest for me to pretend that I found any merit in it' adding that he thought Donald McWhinnie’s production was ‘very much below his normally high standard'), Rhys Adrian's The Man on the Gate is described as 'cheap and vulgar' adding that he thought Adrian, 'lacked even a modicum of talent'. ${ }^{41}$ Even more than Beckett, the dramatists Giles Cooper and Rhys Adrian revealed fundamental differences within the BBC towards the avant-garde.

The combination of the growing interest in Beckett in Britain following the performance of Godot, the broadcast of more experimental drama on the Third Programme and internal pressure on Gielgud led to a three-pronged strategy to broadcast Beckett's work. One was to commission a radio play (All That Fall), the second was to broadcast extracts from his novels and the third was a plethora of radio programmes about Beckett. All of these approaches were evident in 1957.

Following Cecilia Reeves’ invitation in June 1956 to Beckett to write a radio play the decision was taken to send John Morris over to Paris to discuss the details. In that discussion he also acquired from Beckett an option on a radio broadcast in English of an as yet incomplete new stage play, Fin de Partie (subsequently translated as Endgame). What is striking about Morris's intervention at this point is that given his barely concealed philistinism, his extreme dislike of experimental drama (especially Giles Cooper and Rhys Adrian) and even of Beckett's work, this did not prevent him from being particularly keen to make sure Beckett was commissioned to write his first play for the BBC. ${ }^{42}$ The business of discussing details of the production were sensibly left to Donald McWhinnie who was also 
dispatched to Paris to meet Beckett and the two immediately established a friendly and productive working relationship.

Beckett's radio masterpiece, All That Fall was broadcast on 13 January 1957 and was repeated on three occasions, 19 January, 23 February and 19 March. ${ }^{43}$ It was, certainly in the eyes of the BBC, a huge success and Val Gielgud himself was clearly delighted sending this memorandum to McWhinnie,

My warmest congratulations on your outstanding success with the Beckett play. I am more than aware what a tremendously difficult production job this was. [...] Your all over grasp of the problems involved, your exceptional casting, your ingenious use of effects, and your extreme sensitivity of approach, combined to do a fascinating script every sort of justice. Well done. ${ }^{44}$

McWhinnie himself was also delighted, writing to Beckett soon after the first broadcast he said, 'I have never experienced such a widespread and enthusiastic reception to any drama broadcast'. ${ }^{45}$

The press review for All That Fall were largely very positive. Several urged readers to listen to the next broadcast of the play. Roy Walker, writing in The Tribune wrote, 'A All That Fall' is, I insist, the most important and irrestible new play for radio since Dylan Thomas's 'Under Milk Wood' three Januaries ago. ${ }^{46} \mathrm{Val}$ Gilegud may have had severe reservations about Beckett but how delighted he must have been to see one of his Drama Department productions compared to the great triumph of Features, Under Milk Wood.

1957 was a crucial year for the arrival of the avant-garde and experimental drama on $\mathrm{BBC}$ radio. At the same time there were also important stage performances promoting the new wave. Ionesco's The Picture, The Theatre and The Motor Show were all broadcast on the Third Programme together with Rhys Adrian's The Passionate Thinker and Giles Cooper's The Disagreeable Oyster. On the stage, Beckett's second play, Fin de Partie was performed in London on 3rd April and then on the Third Programme in May. Meanwhile, Harold Pinter's first play, The Room was performed by students at Bristol University in May 1957.

In the almost feverish enthusiasm for Beckett following the success of All That Fall there was simply not enough of the great man's drama to broadcast. The solution was to provide readings of Beckett's novels. Beckett had been particularly 
impressed by the performance of the Irish actor, Patrick Magee as Mr Slocum, Clerk of the Racecourse in All That Fall. Magee's delivery was disturbing, harsh and strangely hypnotic and Cronin describes how the two Irishmen immediately connected, 'there was a sense in which, as an actor, he had been waiting for Beckett just as Beckett had been waiting for him.' ${ }^{47}$ Magee recorded an extract from the novel, Molloy (broadcast 10 December 1957) and then an extract from From An Abandoned Work (14 December 1957) both produced by McWhinnie.

The BBC Audience Research Department produced a report on the Molloy reading which provides a graphic sense of the (understandably) confused audience reaction,

As with 'All that Fall' so with these extracts from 'Molloy' and 'from an abandoned work': sharp divisions of opinion characterised the response of the sample audiences, ranging from intense disgust to great admiration and excitement, with a substantial proportion of listeners wavering between the two extremes, several of them confessing themselves uncertain of their critical judgement, reduced almost to incoherence when confronted by Beckett. ${ }^{48}$

In 1958 extracts from other Beckett novels, Malone Dies and The Unnamable were broadcast and then a year later, on 24 June 1959 Beckett's second radio drama, Embers starring another specialist Beckett actor, Jack MacGowran. Beckett's friend and biographer, Anthony Cronin who heard Embers at the time described it as 'difficult to comprehend' and the obscurity of the play seems to have dampened any enthusiasm even among Beckett's many admirers. ${ }^{49}$ In the years that followed Waiting for Godot was finally broadcast on 27 April 1960 and Endgame, after very protracted negotiations, on 22 May 1962. In addition Beckett wrote Words and Music and Cascando for radio, broadcast in 1962 and 1964 respectively.

As Beckett's work became increasingly available and talked-about so the BBC, in the best traditions of public service broadcasting, provided listeners with as many programmes about his work as by him. ${ }^{50}$ This systematic effort to help the listener understand Beckett served not only to reinforce his cultural prestige but to confirm the BBC's commitment to the man and his work. Following earlier quite profound divisions within the BBC over Beckett, by 1960 consensus seems to have emerged and a far more unified, pro-Beckett BBC position was clear. 


\section{Discussion}

In the late 1950s, and in particular 1957 and 1958, the BBC Third Programme became the place to hear some of the most innovative radio drama. This renaissance in dramatic creativity occurred in an institution which was divided between its more conservative and younger, more radical, staff. The evidence presented here suggests that a number of causal factors led to this culturally significant moment and when viewed in their totality provide an understanding of the $\mathrm{BBC}$ as a dynamic public service broadcaster at the height of its powers.

Among the main change agents in BBC Drama in the 1950s the role of a few experimental young producers was clearly very important. In particular, Donald McWhinnie, Val Gielgud's assistant and the producer of Beckett's All That Fall among many other avant-garde productions, and the Script Editor and close friend of Beckett's, Barbara Bray. The well-connected, Paris-based Cecilia Reeves was another important agent in the transnational cultural flow from France to Britain which facilitated the import of Beckett and other central avant-garde dramatists, most notably Eugene Ionesco. Much of this history is well known, but this story of determined young BBC staff as agents of change fits neatly with recent historical emphasis on the importance of the biography of the individual in cultural (and specifically media) histories; the importance of women in the BBC despite their exclusion from senior positions in the 1950s; and the importance of networks of likeminded individuals to promote change. ${ }^{51}$ No doubt the changes in the London theatre contributed to the momentum for change at the BBC; Barbara Bray and her colleagues were very regular visitors to the theatre and saw that as an important part of their job.

The highly pragmatic, and at times contradictory, approaches of both Gielgud and Morris were an essential component in the radio drama renaissance. Gielgud's hatred of Beckett's work (revealed in Martin Esslin's reminiscences) and Morris's dislike of Beckett but contempt for Giles Cooper and Rhys Adrian (stated bluntly in internal memoranda) only temporarily stopped them from allowing extensive broadcasting of all three. Morris's eventual approval was strikingly opportunistic, when he learned of the possibility of acquiring Beckett's Endgame, Morris wrote to Gielgud, 'we may get an option on it before the rats get at it'. ${ }^{52}$ Gielgud's pragmatism perhaps reflects older Reithian notions of public service broadcasting 
and the role of the BBC in public life. For Gielgud personal preferences had to be sacrificed at times for the greater good of the BBC and this was his sense of professional 'duty'. They both realised that the cultural elite were interested in the avant-garde and so for reputational reasons the BBC had to broadcast new work.

The arrival of Harold Pinter on the dramatic scene inevitably put Gielgud and Morris in another spin as personal dislike had to be balanced against a sense of doing the right thing for the BBC. Pinter's early writing was soundly rejected by Gielgud and Morris (and even by Barbara Bray.) The Dwarfs was described, typically, by Gielgud as 'incomprehensible' adding that there were 'several passages in it which I feel should in no circumstances be broadcast at all'. ${ }^{53}$ But at the same time Morris and Gielgud acknowledged that Pinter was being 'discussed by intelligent critics' and so gradually Pinter's dramas were broadcast on the BBC radio as his theatrical productions increased his fame and importance. ${ }^{54}$

BBC radio drama in the 1950s faced competition not only from the emerging phenomenon of BBC television but also, from 1955, ITV television drama. Clearly the Third Programme could not compete for audiences with the exciting and novel experience of television drama but it could at least search for a new dramatic language. This is what motivated Donald McWhinnie and other young producers and is explained in his book on the subject The Art of Radio published in $1959 .{ }^{55}$ The particular approach to a new form of aural drama featured the extensive use of sound effects. At the forefront of this experimentation was Giles Cooper and his adaptation of The Lord of the Flies produced by the pioneering radio producer, Archie Campbell, made extensive use of sound effects. ${ }^{56}$ However, it was Cooper's first drama for the Third Programme, Mathry Beacon (18 June 1956) which 'called for the use of sound effects as an integral, indeed motivating, force behind the drama'. ${ }^{57}$ Similarly, Beckett's All That Fall, broadcast six months later, made experimental use of sound as praised here by the critic, Philip Hope Wallace,

... a miraculous web of sound effects [...] Like a dull bad dream recounted to you by some forcible bore in a Dublin pub, (it) had a tiresome way of penetrating one's aural imagination all next day. This was a feather in the cap of radio drama. ${ }^{58}$ 
Paul Ferris in The Observer commented that the play 'used sound effects in a most painstaking and brilliant fashion'. ${ }^{5}$

The belief that radio drama could be reinvented in the face of television competition on the broadcasting backwater of the Third Programme led to the development of the BBC Radiophonic Workshop, partly inspired by similar approaches in Paris, on 1 April 1958. The first radio drama to make full of experimental sound was Cooper's Under the Loofah Tree and the tradition of BBC radio drama using the services of a dedicated radiophonic sound unit was born. ${ }^{60}$

The broadcasting of avant-garde drama on BBC radio in the 1950s marked a turn from often conventional and cautious output to an apparently enthusiastic acceptance of experimentation in dramatic writing and production. The different factors in this radio renaissance, from enthusiastic young producers to pragmatic (and confused) managers encouraged by new techniques in radiophonic sound were aided by a powerful transnational flow from Paris to London and greatly assisted by the BBC's commitment to public service broadcasting and the role of the $\mathrm{BBC}$ at the cultural vanguard.

\section{Acknowledgements}

I am grateful to the staff at BBC Written Archives Centre and the British Library for their generous assistance. I am also grateful to Heidi Svømmekjær at the University of Copenhagen for supporting and encouraging my interest in radio drama.

\footnotetext{
${ }^{1}$ David Pattie, Modern British Playwriting: the 1950s (London, 2012), 22.

${ }^{2}$ Thomas Hajkowski, The BBC and National Identity in Britain, 1922-1953 (Manchester, 2010).

${ }^{3}$ Kate Murphy, Behind the Wireless: An early history of women at the BBC (Basingstoke, 2015).

${ }^{4}$ Typical of these visits was that made by the Head of Drama, Val Gielgud in September 1957. Cecilia Reeves wrote to him before his arrival saying that she looked forward to his visit but that it was not good from a theatrical point of view 'but I might find enough to make it worth your while'. BBC Written Archives Centre (hereafter, BBC WAC) R19/1630/3, 29 July 1957.

${ }^{5}$ Vivian Mercer, The Irish Times, February 18, 1956.

${ }^{6}$ Martin Esslin, The Theatre of the Absurd $3^{\text {rd }}$ edition (Harmondsworth, 1980), 39.

${ }^{7}$ Pattie, 33-38.

${ }^{8}$ Although as Pattie points out Tennent did bankroll the first British production of Tennessee Williams' a Streetcar Named Desire (1949) and also actively supported the British playwright, Terrence Rattigan (Pattie, 30).

${ }^{9}$ The West End refers to the London's main theatre quarter.

${ }^{10}$ Pattie, 37.

${ }^{11}$ Pattie, 43.
} 
${ }^{12}$ D.Shellard, British Theatre Since the War (New Haven, 1999), 7.

${ }^{13}$ D. Shellard, The Golden Generation: New light on post-war British theatre (London, 2008$), 74$.

${ }^{14}$ Shellard, 2008, 78.

15 Michael Billington, State of the Nation: British Theatre since 1945 (London, 2007), 39.

${ }_{17}^{16}$ Shellard, 1999, 9.

${ }^{17}$ Shellard, 1999, 37.

${ }^{18}$ Ionesco was born in Romania but wrote in French and lived in Paris where he was an important member of the avant-garde.

${ }^{19}$ Asa Briggs, The History of Broadcasting in the United Kingdom. Vols 1-5 (Oxford, 1961, 1965, 1970, 1979, 1995).

${ }^{20}$ This is the position taken by Hendy in Biography and the emotions as a missing 'narrative' in media history: a case study of Lance Sieveking and the early BBC, Media History, 18 (3-4), 361-378.

${ }^{21}$ Leonard Miall, Inside the BBC: British Broadcasting Characters (London, 1994), 123-134.

${ }^{22}$ Val Gielgud oral history, BBC History website http://www.bbc.co.uk/historyofthebbc/bbcmemories/val-gielgud accessed 8 July 2015.

${ }^{23}$ Martin Esslin coined the term 'theatre of the absurd' in his influential book of the same name (New York, 1961).

${ }^{24}$ Gielgud quoted in James Knowlson, Beckett Remembering/Remembering Beckett, (London, 2006).

${ }^{25}$ BBC WAC R 19/1, 632/1, Barbara Bray to Val Gielgud, 3 November 1955.

${ }^{26}$ BBC WAC, R 19/1, 632/1, Gielgud to Lindsey Wellington, 23 November 1955.

${ }^{27}$ Humphrey, 199, The Envy of the World: Fifty years of the BBC Third Programme and Radio 3 (London, 1996), 130.

${ }^{28}$ That loyalty did not extend to the Third Programme itself. When a working party under the Assistant Director of Sound Broadcasting, Richard Marriott questioned Morris he responded by saying that the Third Programme could be closed down because he had no control over the 'supply

departments' and in particular Drama (Carpenter, 168).

${ }^{29}$ Kate Whitehead, The Third Programme: A literary history (Oxford, 1989), 130.

${ }^{30}$ Ian Rodger cited in Whitehead, 139.

${ }^{31}$ BBC WAC R19/1630/3, Reeves to Gielgud, 21 June 1956 (in which she tells Gielgud that she has contacted Beckett directly to ask him to write a radio play).

${ }^{32}$ Anthony Cronin, Samuel Beckett: The last modernist, (New York, 1999), 462.

${ }^{33}$ Oxford Dictionary of National Biography entry for Cecilia Gillie (née Reeves) http://www.oxforddnb.com/index/101061152/Cecilia-Gillie accessed 1 August 2015.

${ }^{34}$ Heppenstall was a writer and producer, his first script for the BBC was performed in 1937 and his career lasted another 40 years. He was particularly associated with French writers, for example translating and producing the work of André Gide for the Third Programme in the early 1950s. Like Cecilia Reeves and Barbara Bray he was an extremely well connected and cultured Francophile determined to bring French culture to post-war Britain.

${ }^{35}$ BBC WAC R Cont 1 (Samuel Beckett, Scriptwriter 1953-62) Reeves to Donald McWhinnie 17 March 1953.

${ }^{36}$ BBC WAC R Cont 1 (Samuel Beckett) E.J.King Bull to Gielgud 15 April 1953.

${ }^{37}$ BBC WAC R Cont 1 (Samuel Beckett) Val Gielgud to E.J.King Bull 20 October 1053.

${ }^{38}$ Billington, 2007.

${ }^{39}$ BBC WAC R Cont 1 (Samuel Beckett ) Mrs Helena Wood to Gielgud 'through Assistant Script Editor, Sound' 20 September 1955.

${ }^{40}$ BBC WAC R Cont 1 (Samuel Beckett ) Raymond Raikes to Gielgud, 29 September 1955.

${ }^{41}$ BBC WAC R19/1630/3, Morris to Gielgud, 26 April 1957.

${ }^{42}$ In a memorandum of 26 April about Cooper and Adrian he wrote about Beckett in these terms, 'however much one may personally dislike his work, [Beckett] is something of a near-genius...'

${ }^{43}$ This is not the place to discuss Beckett's work in any detail, suffice it to say that All that Fall was an extraordinary and innovative drama. A particularly interesting discussion of it is provided by Everett C. Frost, Fundamental Sounds: Recording Samuel Beckett's Radio Plays, Theatre Journal Vol 43 No 3, 361-376 see also my own earlier observations, Out of the Dark: Samuel Beckett and radio, Peripeti 22-2015, 10-21.

${ }^{44}$ BBC WAC R19/1630/3, Gielgud to McWhinnie, 14 January 1957.

${ }^{45}$ BBC WAC R19/1630/3, McWhninie to Beckett, 18 January 1957.

${ }^{46}$ Roy Walker, The Tribune, January 14, 1957. 


\footnotetext{
${ }^{47}$ Cronin, 1999, 470. So inspired by Magee was Beckett that he began to write in February 1958 a draft initially titled 'Magee Monologue' which became one of Beckett's most famous plays, Krapp's Last Tape.

${ }^{48}$ BBC WAC R19/1/, 632/1 Audience Research Report 'Molloy' and 'From An Abandoned Work' 14 January 1958.

${ }^{49}$ Cronin, 490.

${ }^{50}$ Our knowledge of the precise extent of these programmes including their repeats has been facilitated by the launch of the BBC Genome database which provides a searchable list of all BBC programmes listed in the Radio Times. The following are listed as programmes about Beckett between January 1957 and April 1961. 'Waiting for Godot, a Christian interpretation', 9.1.57; Comment, 4.4.57 (plus repeat); 'Samuel Beckett: Poet and Pessimist', 30.4.57; 'A master work of disillusion' (on the translation of Molloy) 15.6.58; ‘The Unsayable’ 19.1.59 (repeated); 'Waiting for What’, 14.4 .61 (4 repeats)

${ }^{51}$ Studying professional and social networks which existed 60 years ago is of course problematic although the existence of private papers can be invaluable. Barbara Bray and Donald McWhinnie's friendship and professional partnership is at least partially revealed in her oral history interview for the BBC. Here she mentions going to the theatre with McWhinnie and identifies him as one of a group of pioneering young producers to which she also belonged. She also expresses her regret that McWhinnie did not get the Head of Radio Drama job on Gielgud's retirement, which instead went to the 'academic' Martin Esslin.

${ }^{52}$ BBC WAC R 19/1630/3 Morris to Gielgud 18 June 1956. On this memorandum in pencil Gielgud wrote the telling words, 'We've asked Cecilia Reeves to get the script if she can'. Once again, Reeves was a persuasive fixer between the BBC and Beckett.

${ }^{53}$ Gielgud quoted in Humphrey Carpenter, 1996, 209.

${ }^{54}$ Carpenter, 209.

${ }^{55}$ Donald McWhinnie, The Art of Radio (London, 1959).

${ }^{56}$ Lord of the Flies, BBC Home Service, 28 August 1955.

${ }^{57}$ Louis Niebur, Special Sound: The creation and legacy of the BBC Radiophonic Workshop (Oxford, 2010), 15.

${ }^{58}$ Hope Wallace writing in Time and Tide quoted in Niebur, 24.

${ }^{59}$ Quoted in Niebur, 24.

${ }^{60}$ BBC Third Programme, 3 August, 1958.
}

Hugh Chignell is Professor of Media History and Director of the Centre for Media History at Bournemouth University. His publications include Public Issue Radio: Talks, news and current affairs in the twentieth century (Palgrave, 2011) and journal articles and book chapters on the history of radio and the BBC. He is currently writing a history of post-war radio drama.

Word count $=7736$ (including endnotes, abstract and biography).

\section{Disclosure statement}

The author has received no financial interest or any other material benefit arising from the application of his research. 